\title{
XXIV. Description, analysis, \&c. of a lamellar pyroxene
}

\section{Lardner Vanuxem}

To cite this article: Lardner Vanuxem (1824) XXIV. Description, analysis, \&c. of a lamellar pyroxene, Philosophical Magazine Series 1, 63:310, 131-134, DOI: 10.1080/14786442408644479

To link to this article: http://dx.doi.org/10.1080/14786442408644479

曲 Published online: 29 Jul 2009.

Submit your article to this journal $₫$

Џll Article views: 2

Q View related articles $\asymp$ 
4. Spirit Lamp.

On the east of north, attracted: moved eastward. On the west of north, ditto: ditto. On the east of south, ditto: moved westward. On the west of south, repelled: ditto.

\section{Aphlogistic Lamp.}

On the east of north, attracted : moved eastward. On the west of north, repelled: ditto.

On the east of south, attracted: moved westward. On the west of south, repelled: ditto.

\section{Heated Plate of Zinc.}

On the east of north, repelled: moved eastward.

On the west of north, attracted: ditto.

On the east of south, repelled: moved westward.

On the west of south, attracted: ditto.

7. Heated Plate of Silver.

On the east of north, attracted : moved eastward.

On the west of north, ditto: ditto.

On the east of south, ditto: moved westward.

On the west of south, ditto: ditto.

The zinc and silver plates, merely heated, prove that positive and negative electricity may be excited apart from chemical action, and that the increment of temperature, superinduced by the chemical action of the acid on the Voltaic plates, may be the source of the communication of electric power.

On the theory of these phænomena I at present forbear to touch ; an extension of such experiments appears to me, however, fraught with the solution which involves the variation of the compass. The thermo-electricity of the globe, as produced by the march of the sun in the plane of the ecliptic toward the tropics of Cancer or of Capricorn, may occasion the grand outlines of variation. Local peculiarities will give rise to particular deviations from the general law.

Your obliged and obedient servant,

Chesternield, Feb. 7, 1824.

J. Murray.

XXIV. Description, Analysis, \&c. of a Lamellar Pyroxene. By LARDNER VANUXEM.*

THIS mineral was brought last year from West Point by Professor Keating and myself; the locality, hitherto unpublished, having been shown to us by Captain Douglass, Mathematical Professor of the Military Academy.

* From the Journal of the Academy of Natural Sciences of Philadelphia, vol. iii. p. 68 . 
The lamellar pyroxene is found about three miles above West Point, on the western side of the river, and near to the water's edge. It is associated with hyaline quartz, black and bronze coloured mica, and feldspar; the latter but in small quantity. These minerals form an aggregate of limited extent, which is a dependant of our sienitic formation, which there covers the whole of the country included under the name of the Highlands of the North River.

The lamellar pyroxene of West Point is identical in all its characters, both external and chemical, with that mineral of Brandywine (Delaware State) which was first considered to be hypersthene, from similarity of colour, and from its presenting the same lamellar structure in one direction, as exhibited by the Labrador mineral; the same which subsequently was analysed and described as an amphibole by Mr. H. Seybert; whose account was published in the Journal of the Academy, vol. ii. p. 139; and to which, more recently, Mr. Nuttall and Dr. Torrey have proposed to give the name of Maclureite, supposing it to be a new mineral. (See Silliman's Journal, vol. v. p. 246.)

Those to whom the characters of these minerals are familiar, will have much less difficulty in identifying the mineral in question with pyroxene, than with either of the other two minerals, with which it has been confounded; and further, will have no reason for believing that it should not be classed with pyroxene, in the present state of our mineralogical knowledge: this being admitted, its new name of Maclureite becomes superfluous and objectionable. To American mineralogists this circumstance cannot but be a subject of regret; for it is not the only attempt* that has been made to confer this merited tribute of respect to our illustrious president; and to no one is it more justly due than to Mr. Maclure.

The West Point mineral occurs principally in lamellar masses; also, but more rarely, in crystals, which though not very perfect, yet are sufficiently well characterized to enable an observer to refer them to the species to which they belong.

The form of the crystals is an octagonal prism, whose angles are about $136^{\circ}$ and $134^{\circ}$; the termimations are too imperfect

* Vide Silliman's Journal, vol. v., No. $\mathcal{Q}$, for Mr. H. Seybert's account " of the Maclureite, or Fluo-silicate of Magnesia, a new mineral species." This is the substance called condrodite, which, as Mr. Seybert found it to contain fluoric acid, he judged to be different from the condrodite of Europe. Since that paper was sent for publication, the same chemist has discovered that this acid likewise exists in the European mineral; so that his proposed name of Maclureite is inadmissible, the substances being the same. 
to ascertain their nature. There are several cleavages, two of which are parallel to four of the alternate sides of the octagon, producing a prism with a rhombic base; these two cleavages are not very easy to obtain, their surface being rough, with but a feeble lustre; the angles which these cleavages form, as determined by the solid so generated, and the measure of their corresponding faces in the crystals, are about $92^{\circ}$ and $88^{\circ}$. This prism may again with ease be divided in the direction of the smaller diagonal; the surfaces produced are very smooth, and of considerable lustre; this is the cleavage to which the mineral owes its highly lamellar structure. In the direction of the larger diagonal, there are indications of a fourth cleavage, but none parallel with the base.

The lamellar masses rarely exceed two inches in their greatest dimension, generally elongated and prismatic, of a dark green colour with a tinge of yellow and bronze. The shades of these colours frequently vary in the same specimen. Scratches glass with ease; fusible before the blowpipe into a shining black globule. Specific gravity about $3 \cdot 24$.

To the result of the analysis* of the lamellar pyroxene of West Point, is adjoined that of Delaware by Mr. H. Seybert, in order to show the complete chemical identity of the two minerals.

\begin{tabular}{|c|c|c|}
\hline Silex & $\begin{array}{l}\text { West Point. } \\
51 \cdot 00\end{array}$ & $\begin{array}{l}\text { Delaware. } \\
52 \cdot 166\end{array}$ \\
\hline Lime & $21 \cdot 00$ & 20.000 \\
\hline Magnesia .................. & $11 \cdot 50$ & $11 \cdot 333$ \\
\hline Alumine ..................... & $3 \cdot 50$ & $4 \cdot 000$ \\
\hline $\left.\begin{array}{c}\text { Deutoxide of iron with a } \\
\text { trace of manganese }\end{array}\right\}$ & $11 \cdot 53$ & $10 \cdot 733$ \\
\hline Water........................ & $1 \cdot 00$ & $1 \cdot 266$ \\
\hline Loss & 47 & 502 \\
\hline & .00 & $100 \cdot 000$ \\
\hline
\end{tabular}

The mineral of West Point differs from hypersthene in the angles given by their cleavages, which are different; those of hypersthene being as the numbers 100,80 , and 50 ; and also

* The analysis of the mineral was made in the following manner, having previously ascertained that it was composed of silex, lime, magnesia, alumine, and oxide of iron, with a trace of manganese:-Pulverised and calcined a portion of the mineral for water; fused another portion with potash in order to decompose the mineral; dissolved the whole in nitro-muriatic acid, then evaporated to dryness; added acidulated water, and filtered, this gave the silex; precipitated the metals and alumine by hydrosulphate of ammonia; separated the alumine by potash; threw down the lime by oxalate of potash, and obtained the magnesia by boiling the liquor with potash. 


\section{Mr. Vanuxem's Description of a Lamellar Pyroxene.}

in the latter being infusible and different in its composition. From amphibole, because there are but two cleavages in this mineral, obtainable with the same ease, and both possessing the same degree of smoothness and lustre, in short, absolutely identical. 'The angles which they form are those of $124^{\circ} 34^{\prime}$, and $55^{\circ} 26^{\prime}$, angles which do not occur in the West Point mineral. The chemical elements of amphibole and pyroxene are the same, the difference being in the proportion of their constituents.

The essential character of pyroxene is derived from its crystallization. The primitive form determined by its cleavages, and with the aid of its secondary forms, is an oblique prism with a rhombic base; angles of the prism, by the common goniometer, $92^{\circ}$ and $88^{\circ}$, or more accurately by the secondary forms, joined to certain theoretical considerations, $92^{\circ} 18^{\prime}$, and $87^{\circ} 42^{\prime}$. The cleavages of pyroxene, as given by its several varieties, are parallel to the faces of the prism and diagonals of the base. One of the secondary forms of the pyroxene is an octagonal prism, with angles of $136^{\circ}$ and $134^{\circ}$ by the goniometer, or corrected in the aforementioned manner $136^{\circ} 09^{\prime}$ and $133^{\circ} 51^{\prime}$. The degree of smoothness and facility of obtaining the different cleavages of pyroxene, vary considerably in the different varieties of this mineral. Sometimes a cleavage which is very evident in one variety is indistinct or scarcely to be perceived in another. Thus in certain volcanic pyroxenes the cleavage parallel to the larger diagonal is the most lamellar (according to Haüy), and none exists in the direction of the base, whilst in other pyroxenes that of the base is pre-eminent; so that this character, in all cases, must be considered as very secondary in value to the character which depends upon the angles of the cleavages and those of the crystals.

Thus the mineral of West Point and of Delaware corresponds with pyroxene in the form and value of the angles of the primitive form, and those of the octagonal prism; in the cleayages parallel with the sides of the primitive form, and diagonals of the same: in hardness, action with the blowpipe, specific gravity and chemical composition. The only difference being this, that its lamellar structure is parallel to the smaller and not to the larger diagonal, as in volcanic pyroxene, a circumstance which cannot be considered of specific importance. 